\title{
The Acclimation of European Sea Bass (Dicentrarchus labrax) to Temperature: Behavioural and Neurochemical Responses
}

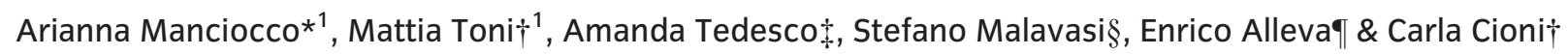 \\ * Institute of Cognitive Sciences and Technologies, Consiglio Nazionale delle Ricerche, Rome, Italy \\ $\uparrow$ Department of Biology and Biotechnology "Charles Darwin”, Sapienza University, Rome, Italy \\ \$ Model Organisms in Biomedical and Veterinary Research, Doctorate School in Veterinary Science for Animal Production, Health and Food Safety, \\ University of Naples Federico II, Rome, Italy \\ $\S$ Dipartimento di Scienze Ambientali, Informatica e Statistica, CEMAS, Center for Estuarine, Coastal, Marine Sciences, Universit_a Ca' Foscari \\ Venezia, Venice, Italy \\ I Section of Behavioural Neuroscience, Department of Cell Biology and Neuroscience, Istituto Superiore di Sanità, Rome, Italy
}

\author{
Correspondence \\ Arianna Manciocco, Institute of Cognitive \\ Sciences and Technologies, Consiglio \\ Nazionale delle Ricerche, via Ulisse \\ Aldrovandi 16/b, 00197 Rome, Italy. \\ E-mail: arianna.manciocco@istc.cnr.it \\ Received: March 28, 2014 \\ Initial acceptance: April 29, 2014 \\ Final acceptance: August 19, 2014 \\ (L. Fusani) \\ doi: 10.1111/eth.12315 \\ ${ }^{1}$ Authors contributed equally. \\ Keywords: behaviour, ChAT, climate \\ change, Dicentrarchus labrax, temperature, \\ sea bass, water
}

\begin{abstract}
Studies on fish behavioural and neurophysiological responses to water temperature change may contribute to an improved understanding of the ecological consequences of global warming. We investigated behavioural and neurochemical responses to water temperature in European sea bass (Dicentrarchus labrax) acclimated to three temperatures $\left(18,22\right.$ and $28^{\circ} \mathrm{C}$ ). After $21 \mathrm{~d}$ of acclimation, three groups of 25 fish each were exposed to four behavioural challenges (foraging, olfactory, aversive and mirror tests). The expression of choline acetyltransferase (ChAT) was then analysed by Western blotting in CNS homogenates (from a subset of the same fish) as a marker for cholinergic system activity. In both foraging and olfactory tests, fish acclimated to $28^{\circ} \mathrm{C}$ exhibited significantly higher arousal responses than fish acclimated to lower temperatures. All specimens showed fright behaviour in the aversive test, but the latency of the escape response was significantly less in the fish at $28^{\circ} \mathrm{C}$. Finally, the highest mirror responsiveness was exhibited by the fish acclimated to $22^{\circ} \mathrm{C}$. As in the case of cholinergic neurotransmission, significantly higher ChAT levels were detected in the telencephalon, diencephalon, cerebellum and spinal cord of fish acclimated to 22 or $28^{\circ} \mathrm{C}$ in comparison with those maintained at $18^{\circ} \mathrm{C}$. Lower ChAT levels were detected in the mesencephalon (optic tectum) at 22 and $28^{\circ} \mathrm{C}$ than at $18^{\circ} \mathrm{C}$. These data indicate that neuronal functions are affected by water temperature. Increases or decreases in ChAT expression can be related to the functional modulation of brain and spinal cord centres involved in behavioural responses to temperature change. Overall, the results of this study suggest that the environmental temperature level influences behaviour and CNS neurochemistry in the European sea bass.
\end{abstract}

\section{Introduction}

An increase in temperature is thought to be one of the principal effects of climate change (IPCC 2007). Indeed, an increase of a few degrees in the water temperature modifies the structure and functionality of sea and estuarine communities, affecting the abundance and the geographical distribution of living organisms (Kankaala et al. 2002; Cairns et al. 2005; Hiddink \& ter Hofstede 2008; Daufresne 2009), primarily in highly vulnerable environments such as lagoons and coastal wetlands (Eisenreich 2005).

Water temperature is a crucial factor for all aquatic ectothermic species, including fish (Atkinson 1996; Jobling 1996; Manciocco et al. 2014). Indeed, thermal acclimatisation can affect fish growth, reproduction, 
spontaneous activity, feeding behaviour and metabolism (Pörtner 2002).

Dicentrarchus labrax is a eurythermal and euryhaline species that spends its early life in transitional environments (i.e. lagoons) before the adults move to the sea and then return to estuarine waters for reproduction (Blaber et al. 1989; Pickett \& Pawson 1994). Several studies have analysed the impact of water temperature on different aspects of sea bass physiology and biochemistry, such as growth (Vinagre et al. 2009), morphology (Sfakianakis et al. 2006), metabolism (Person-Le Ruyet et al. 2004), protein utilisation (Peres \& Oliva-Teles 1999), sex determination (Saillant et al. 2002; Navarro-Martin et al. 2011) and swimming speed (Koumoundouros et al. 2002; Claireaux et al. 2006). In this regard, it was reported that sea bass juveniles cease growing at $11-15^{\circ} \mathrm{C}$ and grow more rapidly at $22-25^{\circ} \mathrm{C}$, with upper and lower thermal limits at $2-3^{\circ} \mathrm{C}$ and $30-32^{\circ} \mathrm{C}$, respectively (Barnabé 1991). Moreover, positive correlations have been found between temperature, food absorption and growth rate in the same species (Russell et al. 1996; Person-Le Ruyet et al. 2004).

In natural environments, fish migrate towards regions with a more suitable temperature. However, this study may have ecological relevance because the experiments performed allowed us to assess the effect of water temperature variations on behaviour and neurochemistry. From a global warming perspective, ethological studies strictly associated with neurochemical analyses under controlled laboratory conditions appear necessary to obtain detailed information on the species-specific coping styles affected by the temperature modifications, particularly in terms of the effects of temperature variations on social, lifethreatening and feeding behaviours.

Nevertheless, although data are relatively abundant in the literature, the effects of water warming on behaviour and CNS activity have not been investigated in relevant commercial species such as the European sea bass. Recent experiments performed by our group on wild European sea bass juveniles (standard length 3-4 cm) captured from the Venetian lagoon have indicated that thermal acclimation may influence several quantitative components of the antipredator behaviour directed towards a live fish and an aerial stimulus. Moreover, a Western blot (WB) analysis performed on the same specimens showed that the level of ChAT expression is lower in the brains of fish acclimated to $26^{\circ} \mathrm{C}$ than in those at $18^{\circ} \mathrm{C}$ (Malavasi et al. 2013). These results indicated that sea bass juveniles from natural lagoons are sensitive to thermal regimes. This finding should be confirmed in different fish stocks.

The aim of this study was to further investigate the behavioural and neurochemical responses to temperature change of European sea bass juveniles (s.l. $10 \mathrm{~cm}$ ) from a commercial hatchery. The greater size of the fishes used in the present work allowed us to dissect the main brain regions, thus obtaining a more accurate topographic analysis of ChAT expression. Moreover, the behavioural scoring included exploratory and social traits not previously described (Malavasi et al. 2013).

The acclimation temperatures used in this study were based on Barnabé (1991), who reported the $21-25^{\circ} \mathrm{C}$ interval as the optimal growth range for the sea bass. The three selected temperatures were situated slightly below $\left(18^{\circ} \mathrm{C}\right)$, within $\left(22^{\circ} \mathrm{C}\right)$ and above $\left(28^{\circ} \mathrm{C}\right)$ the best thermal range. Temperatureacclimated fish were subjected to four behavioural challenges (foraging, olfactory, aversive and mirror test), and their responsiveness was compared. The expectation was that fish at the highest temperature would be more responsive to experimental challenges than fish at lower temperatures and would show a higher level of exploratory behaviour during the olfactory, aversive and mirror tests and more feeding events in the foraging test. Indeed, an increased interest in food is expected in ectothermic animals as a response to an enhanced metabolic rate due to high temperature (Cossins \& Bowler 1987).

As a marker for CNS activity, the expression of choline acetyltransferase (ChAT) was investigated, as ChAT is reportedly the enzyme responsible for ACh synthesis in cholinergic neurons (Eckenstein et al. 1981). According to the literature, thermal acclimation affects ChAT expression and activity in both vertebrate (Hebb et al. 1972; Poli et al. 1997; Malavasi et al. 2013) and invertebrate neurons (Salvaterra $\&$ McCaman 1985; Tajima \& Salvaterra 1992; Takagawa \& Salvaterra 1996). Moreover, experiments on goldfish have demonstrated that ACh is directly involved in behavioural thermoregulation (Crawshaw $\&$ Wollmuth 1992), which is the main mechanism of thermal regulation in fish. In this study, ChAT neurochemistry was analysed with WB testing in the brain and spinal cord.

\section{Materials and Methods}

\section{Fish Collection and Maintenance}

A total of 216 juvenile sea bass of mean standard length $10 \pm 1$ (Standard error, SE) cm were collected 
from a commercial hatchery between Mar. and Nov. 2012 (Panittica Pugliese, Brindisi, Italy). According to Giffard-Mena et al. (2011), this size corresponds to fish that are approximately 2 yr old. Upon arrival at the laboratory, the fish were randomly allocated to $180 \mathrm{~L}(100 \times 40 \times 50 \mathrm{~cm})$ indoor well-aerated glass aquaria (12 fish per tank, designated 'home tank') supplied with recirculated and filtered seawater (300 l/hr), with salinity averaging $15 \pm 1$ (SE) \% and a temperature of $19 \pm 1(\mathrm{SE}){ }^{\circ} \mathrm{C}$, replicating the housing conditions of the hatchery that provided the fish. The same chemical-physical conditions experienced by fish in the source hatchery were maintained to reduce the potential stress level of the fish. During the quarantine period (1 mo long), a procedure directed against external skin parasites was applied for $1 \mathrm{wk}$ in the form of a disinfecting agent (Oidimol Dajana Pet, Brno, Czech Republic) at a concentration of $0.2 \mathrm{ml} / \mathrm{l}$ as indicated by the manufacturer's directions for use. To our knowledge, no data are available to suggest that such a procedure could affect the neurochemical variables examined in this study. Furthermore, on the basis of data from the literature, the salinity was gradually reduced to $5 \pm 2$ (SE) \% during the quarantine period to minimise the risk of spread of pathogens (Chang \& Plumb 1996). The fish were maintained under an artificial photoperiod (12:12 light/dark cycle) and fed daily by hand with commercial dry pellets ( $2 \%$ of body mass) (Aqualim, France). To ensure good water quality, a constant flow of filtered water (300 l/hr) was maintained with internal filter systems in each aquarium, faeces and the remaining food items were removed from the animal tanks at least three times per week, salinity was checked with a hand-held refractometer and $\mathrm{pH}$, and changes in the concentrations of nitrites and nitrates were monitored in all aquaria. During the tank-cleaning operations, a water exchange of approximately $20-30 \%$ per week was performed to restore the correct volume of water and maintain its chemical-physical parameters.

The mortality rate averaged $20 \%$ for all tanks during the quarantine period, primarily due to the presence of pre-existing parasitic organisms. Specifically, two or three fish died in each tank.

Moreover, two fish died during the experimental period (see 'Experimental Procedure'). All procedures of maintenance complied with both the requirements for the care and accommodation of fish stated in Annex III, Section B of Directive 2010/63/EU (EU 2010) and Recommendation 2007/526/EC on guidelines for the care of animals used for experimental and other scientific purposes (EC 2007).
At the end of the behavioural tests, to minimise the sacrifice of animals, a total of 38 subjects were captured haphazardly with a hand net and were euthanised for neurochemical analysis. The remaining animals were kept in tanks under stock conditions $\left(19^{\circ} \mathrm{C}\right)$ and eventually used in other experiments.

\section{Experimental Procedure}

The experimental temperatures of 18,22 and $28^{\circ} \mathrm{C}$ were achieved, in 1, 3 and 9 d, respectively, by gradually changing the water temperature in the home tanks by $1^{\circ} \mathrm{C}$ per day beginning from the initial temperature of $19^{\circ} \mathrm{C}$. When these temperatures were reached, the experimental period began. All fish were kept at the experimental temperatures for $21 \mathrm{~d}$ (designated 'thermal treatment' below). Six aquaria were used for each experimental temperature. The water temperature was checked twice daily (10:00 and 17:00 local time) and showed a mean standard error of $\pm 1^{\circ} \mathrm{C}$ relative to the desired value. Opaque panels were located between tanks to prevent visual contact between fish in different tanks.

At the end of the 21-d-long thermal treatment, four behavioural challenges (foraging, olfactory, aversive and mirror test) were presented to the subjects (150 in total). For each trial, two fish were captured haphazardly by a hand net and moved from the home tanks to the behavioural tanks (61 l, indoor, $53.5 \times 40.0 \times 36.5 \mathrm{~cm})$. In a pilot study, persistent freezing behaviour was observed in singly housed subjects. Conversely, swimming activity normally occurred when two fish were captured and then housed together in the behavioural tanks. For this reason, pairs of animals to be used in the behavioural tests $(\mathrm{N}=25)$ were moved for each trial to the behavioural tanks (for a total of 50 subjects for each single thermal treatment). The behavioural tanks were identical in water temperature and salinity to the home tanks. Sanyo video cameras (VPC-GHl, Vietnam) were placed approximately $50 \mathrm{~cm}$ in front of the behavioural tanks $24 \mathrm{hr}$ before the beginning of the behavioural challenges. This procedure permitted animals to become familiar with the camera. The position of the cameras allowed video coverage of the entire surface of the tanks. Video recording always began 2 min before the start of the behavioural tests. The cameras were turned on without sudden movements, and no evidence of stress was observed (for example, no change in swimming movements was ever observed). The fish were used to the presence of human beings close to the tanks (e.g. for routine cleaning and feeding procedures). 
The four behavioural challenges were performed in sequence, with a time interval of 30 min between two consecutive tests. On the basis of behavioural observations conducted during the pilot study, a $30 \mathrm{~min}$ long intertest interval was found to be an appropriate period of time to allow the fish to resume normal swimming activity after each of the four behavioural challenges presented.

In all four tests, the experimenter placed herself behind a panel located near the experimental tanks and proceeded to introduce the objects used in the tests. The fish never showed any changes in activity that could be attributed to fear of the experimenter or surprise.

To enhance the interest of the fish in the food items presented in the foraging and olfactory tests, no food was provided during a period of $24 \mathrm{hr}$ before the day of the experiment.

\section{Foraging Test}

The goal of this test was to assess the effects of temperature change on foraging behaviour. The ability to forage was tested using frozen larvae of Chironomus salinarius (mean length $1 \mathrm{~cm}$ ). These larvae were selected for the experiment because they are commonly used as feeding enrichment in recreational aquaria and are, thus, easily available in large quantities. As prior experience plays a role in the foraging behaviour of certain fish species (Brown et al. 2003), a swarm of frozen larvae was released three times (once weekly) in all the home tanks during the $21 \mathrm{~d}$ of thermal treatment. At the start of the trial, a swarm of larvae (approximately 30 larvae) was delivered to a side of the behavioural tank by a syringe. Fish behaviour was video-recorded for $5 \mathrm{~min}$ soon after the release of the food. The behaviours considered were as follows: 'first biting', defined as the first bite given by the fish to food item; 'feeding', catching and/or eating a food item as a result of darting movements; 'fin raising', rapid and repeated erection and lowering of dorsal fins; and 'fast swimming', rapid and darting movements across the behavioural tank (Table 1).

\section{Olfactory Test}

Fish rely on olfaction for food detection, recognition and selection (Atema 1980; Hara 1993). Indeed, previous studies on sea bass have reported that the addition of an attractive amino acid mixture to the diet enhanced voluntary food intake, weight gain and protein utilisation by this species (Mackie $\delta$ Mitchell
Table 1: Description of the behavioural patterns considered (Pickett \& Pawson 1994)

\begin{tabular}{|c|c|c|}
\hline Test & Behaviour & Description \\
\hline \multirow[t]{3}{*}{ Foraging } & Feeding & $\begin{array}{l}\text { Catching and eating food item from } \\
\text { below by darting movement }\end{array}$ \\
\hline & Fin raising & $\begin{array}{l}\text { Fast and repeated erection and lowering } \\
\text { of dorsal fins }\end{array}$ \\
\hline & Fast swimming & Fast darting movement across the tank \\
\hline \multirow[t]{3}{*}{ Olfactive } & $\begin{array}{l}\text { Swimming close } \\
\text { to the cue }\end{array}$ & Fish presence in a $8 \mathrm{~cm}^{2}$ around the cue \\
\hline & $\begin{array}{l}\text { Contact with } \\
\text { the cue }\end{array}$ & $\begin{array}{l}\text { Touching and knocking the cue by the } \\
\text { mouth }\end{array}$ \\
\hline & Fin raising & $\begin{array}{l}\text { Fast and repeated erection and lowering } \\
\text { of dorsal fins }\end{array}$ \\
\hline \multirow[t]{5}{*}{ Aversive } & Escape response & $\begin{array}{l}\text { Darting away following the fallen down } \\
\text { object }\end{array}$ \\
\hline & $\begin{array}{l}\text { Swimming close } \\
\text { to the object }\end{array}$ & Fish presence in a $8 \mathrm{~cm}^{2}$ around object \\
\hline & $\begin{array}{l}\text { Contact with the } \\
\text { object }\end{array}$ & Touching the object by the mouth \\
\hline & Inactivity & $\begin{array}{l}\text { Staying motionless through the water } \\
\text { column with fin movements }\end{array}$ \\
\hline & Freezing & $\begin{array}{l}\text { Staying motionless on the bottom } \\
\text { without fin movements }\end{array}$ \\
\hline \multirow[t]{3}{*}{ Mirror } & $\begin{array}{l}\text { Contact with the } \\
\text { mirror }\end{array}$ & $\begin{array}{l}\text { Touching and knocking the mirror by } \\
\text { the mouth }\end{array}$ \\
\hline & C-start reaction & $\begin{array}{l}\text { Showing a C-shape bending of the body } \\
\text { towards right or left in front of mirror. }\end{array}$ \\
\hline & Arousal & $\begin{array}{l}\text { Fast and repeated erection and lowering } \\
\text { of first dorsal fin, zigzag swimming, } \\
\text { quickly buccal pumping, directed at } \\
\text { and within } 8 \mathrm{~cm} \text { from the mirror }\end{array}$ \\
\hline
\end{tabular}

1982; Dias et al. 1997), supporting the role of olfaction as a key sense for foraging in D. labrax.

In this test, the olfactory cue was represented by Sarcophaga carnaria larvae, which are commonly used as live bait by anglers. Ten Sarcophaga carnaria larvae were put into a tea infuser and immersed at middle height in the water column on one side of the 'behavioural tank'. Fish gained experience with both the empty tea infuser and the tea infuser containing $S$. carnaria as a result of the introduction of these objects to the home tanks three times (one time weekly during the $21 \mathrm{~d}$ of thermal treatment) to avoid any effect that the novelty of the stimulus might have on fish behaviour. The duration of video recording was $10 \mathrm{~min}$. The measured behaviours were as follows: 'swimming close to the cue', defined as the presence of the fish in an $8 \mathrm{~cm}$ square around the olfactory stimulus; 'contact with the cue', the action of touching and knocking the cue with the mouth or the side of the body; and 'fin raising', the rapid and repeated erection and lowering of the dorsal fins (Table 1). To score the behaviour 'swimming close to 
the cue', a $64 \mathrm{~cm}^{2}$ area was defined around the stimulus by attaching a transparent film inscribed with vertical and horizontal lines to the front wall of the behavioural tank. Swimming activity was measured by counting the number of entries in the square area and recording the time spent within that area.

\section{Aversive Test}

The aim of this test was to reproduce the water movement and vibrations due to the immersion of a potentially dangerous element (e.g. fishing net, float, avian predator) to investigate the response to an aversive stimulus. The stimulus chosen was a rubber ball $4 \mathrm{~cm}$ in diameter thrown into the water from a shelf located $0.5 \mathrm{~m}$ over the experimental tanks. The experimenter (AT) waited to throw the ball until both fish were stationary under the shelf. Fish behaviour was recorded for $10 \mathrm{~min}$ after the aversive stimulation. The behaviours analysed were as follows: 'escape response', defined as an escape with darting movements following the impact of the ball; 'swimming close to the object', the presence of the fish in an $8 \mathrm{~cm}$ square area around the ball; 'contact with the object', touching the ball with the mouth or the side of the body; 'inactivity', lack of motion in the water column and performance only of fin movements; and 'freezing', lying motionless on the tank bottom with no fin movements (see Table 1). The 'escape response' was recorded soon after the aversive stimulation. All other behaviours were recorded within a $64 \mathrm{~cm}$ square area that was defined around the plastic ball by attaching a transparent film ruled with vertical and horizontal lines to the front wall of the behavioural tank. Swimming activity was measured by counting the number of entries and recording the time spent by the focal fish within the square area.

\section{Mirror Test}

Mirror images are often used to investigate fish predator inspection (Milinski 1987), but a social response to this stimulus has also been observed (Meliska et al. 1980; Miklosi et al. 1998). Furthermore, many fish display a systematic preferential use of one eye, and their laterally placed eyes influence their everyday behaviour (Tsubokawa et al. 2009).

Our goal was to measure the responsiveness of $D$. labrax to its mirror image. A mirror was carefully placed outside the behavioural tank along the short side, and the fish were then recorded for $5 \mathrm{~min}$. Measured behaviours were the following: 'contact with the mirror', defined as touching and knocking the side of the mirror with the mouth; latency to contact, estimated as the elapsed time between the presentation of the mirror and the first contact with it; 'C-start right reaction', bending the body towards the right in front of the mirror side and making a C-shaped movement; 'C-start left reaction', bending the body towards the left in front of the mirror side and making a C-shaped movement; 'arousal', rapid and repeated erection and lowering of dorsal fins associated with zigzag swimming and/or rapid buccal pumping, all behaviours directed within a distance of $2 \mathrm{~cm}$ from the mirror (see Table 1).

\section{Behavioural Data Analysis}

Tank effects were minimised by keeping all aquaria in identical care regime and macro- and micro-environment. Then, statistical analysis to investigate tank effects was conducted within each temperature and no effect was found (for details, see below).

The experimental unit was the individual. All experimental fish were tested out of their home tanks, isolated from the social group, and the behaviour of only one fish (called the focal subject) for each pair of the tested animals was analysed (total subjects: $\mathrm{N}=75$; subjects per temperature: $\mathrm{N}=25$ ). This procedure guaranteed the independence of data. The first animal that moved was defined as the focal subject. The second individual acted as a companion, and its behaviour was not analysed. The recognition of the focal subject occurred on the basis of slight body differences (e.g. the size, colour and shape of the caudal fin). The video recordings were replayed and analysed using Noldus Observer recording software (Noldus, Wageningen, The Netherlands) on a laptop (Asus K52F).

A total of 16 variables were considered across four different behavioural tests, with four behaviours measured for each test on average. In the olfactory test, 'swimming close to the cue' and 'contact with the cue' were analysed both separately and together (named 'interest in the cue'). In the aversive test, 'swimming close to the object' and 'contact with the object' were analysed both separately and together (named 'interest in the object').

The data did not obey the assumptions of normality and homoscedasticity needed for parametric statistics. Therefore, a Kruskal-Wallis test was performed, and a Mann-Whitney $U$-test was used for post hoc comparisons. The Bonferroni-Holm correction was applied for multiple comparisons and not for measured variables (Perneger 1998). The Bonferroni-Holm correction was preferred to the 
Bonferroni method, as an analysis of post hoc comparisons with a Student's unpaired $t$-test has shown that statistically significant differences vanished after the application of a Bonferroni correction. Therefore, this method is considered overly conservative (Aickin \& Gensler 1996). Data analyses were performed with Statview 5.0 (SAS Institute Inc.). The significance level used for the tests was 0.05 .

\section{Sample Collection and Analysis for ChAT Neurochemistry}

A total of 38 fish haphazardly chosen from those previously subjected to the behavioural tests were used for neurochemical analyses (Table 2). The number of fish sampled for these analyses was restricted to minimise the sacrifice of animals.

Thirty-six fish (12 for each temperature) were analysed with the WB method to evaluate ChAT expression in the CNS. Two additional fish acclimated to $18 \pm 1(\mathrm{SE}){ }^{\circ} \mathrm{C}$ were processed for ChAT immunofluorescence to verify the specificity of the polyclonal anti-ChAT antibody used in the WB.

For the WB analysis, fish were euthanised with an overdose of 2-phenoxyethanol $(8 \mathrm{ml} / \mathrm{l})$, their weight and standard length were measured, and their brain and spinal cord were then rapidly dissected out. Brain samples from 18 specimens (six for each temperature) were processed as a whole, whereas brains from 18 other specimens (six for each temperature) were further subdivided into samples corresponding to the five main brain regions: telencephalon (including olfactory bulbs and preoptic region), diencephalon, mesencephalon (midbrain optic lobes), cerebellum and brainstem (Fig. 5a). Tissues were placed in RNA Later (Ambion, Austin, TX) at $-70^{\circ} \mathrm{C}$ until they were processed.

In the WB analysis, pools of tissues from three animals were processed. Samples were homogenised and analysed in triplicate following the protocol previously described in Malavasi et al. (2013). In the present study, $50 \mu \mathrm{g}$ of protein was loaded in each lane and separated in 8\% SDS-polyacrylamide gels (SDS-PAGE). ChAT detection was achieved by the same ChAT polyclonal antibody (Cat.\# AB 144P, Lot.\# NG1752017; Millipore, Temecula, CA, USA, dilution $1: 3000)$ previously used successfully in a WB analysis performed on the whole-brain homogenates of European sea bass juveniles (Malavasi et al. 2013). Normalisation was performed against b-actin (actin antibody at 1:3000, Santa Cruz Biotechnology, Dallas, TX, USA) or glyceraldehyde 3-phosphate dehydrogenase (GAPDH antibody at 1:2500, Abcam, Cambridge, UK) expression. In the controls, the primary antibody was omitted.

The reactivity of the ChAT antibody was verified by immunofluorescence in brain sections from fish acclimated to $18 \pm 1$ (SE) ${ }^{\circ} \mathrm{C}$. Fish were transcardially perfused with $4 \%$ paraformaldehyde (PFA) in phosphate-buffered saline (PBS, $0.01 \mathrm{M}, \mathrm{pH} 7.4$ ). The brain was dissected out, post-fixed in PFA for $24 \mathrm{hr}$ and cryoprotected in PBS containing $30 \%$ sucrose at $4^{\circ} \mathrm{C}$ for at least $36 \mathrm{hr}$. Samples were successively embedded in O.C.T. compound (Tissue-Tek II, Quiagen, Italy), frozen and cut into $20-\mu \mathrm{m}$ transverse sections in a cryostat. Consecutive serial sections collected on microscope slides and sections containing the midbrain tectum were selected and processed for immunofluorescence. Briefly, sections were permeabilised with PBS plus $0.5 \%$ Triton-X-100 (PBST), blocked with $3 \%$ bovine serum albumin in PBST for $30 \mathrm{~min}$ and successively incubated with the anti-ChAT antibody (diluted 1:50) overnight at $4^{\circ} \mathrm{C}$. Sections were then incubated for $\mathrm{l} \mathrm{hr}$ at room temperature with a CY3-conjugated anti-goat antibody (diluted 1:50, Sigma-Aldrich, St. Louis, MO, USA). After several washes with PBS, sections were mounted on slides, coverslipped and observed with a fluorescence microscope. In the controls, the primary antibody was omitted.

Table 2: Number of fishes analysed

\begin{tabular}{|c|c|c|c|c|c|c|c|c|}
\hline \multirow[b]{2}{*}{$\begin{array}{l}\text { Acclimation } \\
\text { temperature }\end{array}$} & \multicolumn{2}{|c|}{ Behavioural test } & \multicolumn{6}{|c|}{ Neurochemical analysis } \\
\hline & $\begin{array}{l}\text { N. of } \\
\text { fishes } \\
\text { tested }\end{array}$ & $\begin{array}{l}\text { N. of } \\
\text { fishes } \\
\text { analysed }\end{array}$ & $\begin{array}{l}\text { N. of } \\
\text { fishes } \\
\text { analysed }\end{array}$ & $\begin{array}{l}\text { Method of } \\
\text { analysis }\end{array}$ & $\begin{array}{l}\text { Whole-brain } \\
\text { analysis } \\
\text { (pool n. 1) }\end{array}$ & $\begin{array}{l}\text { Whole-brain } \\
\text { analysis } \\
\text { (pool n. 2) }\end{array}$ & $\begin{array}{l}\text { Brain regions } \\
\text { analysis } \\
\text { (pool n. 1) }\end{array}$ & $\begin{array}{l}\text { Brain regions } \\
\text { analysis } \\
\text { (pool n.2) }\end{array}$ \\
\hline \multirow[t]{2}{*}{$18^{\circ} \mathrm{C}$} & 50 & 25 & 2 & $\mathrm{IHC}$ & & & & \\
\hline & & & 12 & WB & 3 & 3 & 3 & 3 \\
\hline $22^{\circ} \mathrm{C}$ & 50 & 25 & 12 & WB & 3 & 3 & 3 & 3 \\
\hline $28^{\circ} \mathrm{C}$ & 50 & 25 & 12 & WB & 3 & 3 & 3 & 3 \\
\hline Total & 150 & 75 & 38 & & & & & \\
\hline
\end{tabular}




\section{Ethical Note}

All experiments have been performed in accordance with Directive 2010/63/EU (European Union (EU) 2010) with Italian administrative order DM 256/2012 of the Italian Ministry of Health. The experiment was designed to minimise the impact on the welfare of animals by including a filter system whose physical structure was used as cover by the fish and by replicating the chemical-physical conditions experienced by fish in the hatchery on arrival at the laboratory. The number of animals tested at each temperature was chosen to comply with the reduction principle but, at the same time, to recognise interindividual variability and to guarantee the scientific objectives of the experiment. A pilot study was previously conducted to refine the methodology and to minimise stressful conditions during the experimental challenges (for details, see the paragraph 'Experimental procedure') (see Russell \& Burch 1959). In particular, fish euthanasia was performed by an overdose of 2phenoxyethanol. This chemical is used for anaesthesia in freshwater fish research for routine work because of its rapid effect and rapid recovery time if exposure to the drug is not overly long (Idler et al. 1961; Sehdev et al. 1963). The data available in the literature primarily refer to the concentrations of 2-phenoxyethanol used for fish anaesthesia and not for euthanasia. In a pilot study, we tested five different concentrations (1, 2, 4, 6 and $8 \mathrm{ml} / \mathrm{l}$ ) of 2-phenoxyethanol to induce rapid euthanasia in fish. The concentration of $8 \mathrm{ml} / \mathrm{l}$ was the most effective in inducing rapid euthanasia, and no strong behavioural reactions were observed.

\section{Results}

A total of 150 fishes acclimated for $21 \mathrm{~d}$ at 18, 22 and $28^{\circ} \mathrm{C}$ were subjected to the behavioural tests. The behaviour of 75 subjects was then statistically analysed. Among these fish, a subsample of 38 (14 acclimated at $18^{\circ} \mathrm{C}, 12$ at $22^{\circ} \mathrm{C}$ and 12 at $28^{\circ} \mathrm{C}$ ) were haphazardly captured with a hand net, euthanised, measured and used for neurochemical analyses (Table 3). Both weight and standard length acrosstemperature differences were statistically significant (weight: $\mathrm{H}_{2}=16.615, \mathrm{p}=0.0002$; standard length: $\mathrm{H}_{2}=11.577, \quad \mathrm{p}=0.0031$ ), post hoc comparisons showed the mean fish standard length at $18^{\circ} \mathrm{C}$ differing from that at $28^{\circ} \mathrm{C}$ but not from that at $22^{\circ} \mathrm{C}$. The fish acclimated at 22 and $28^{\circ} \mathrm{C}$ showed an increase in average weight of 1.3 and 1.7 times, respectively, and an increase in average standard length of 1.1 and 1.2
Table 3: Weight and standard length (s.l.) of fish killed for immunofluorescence and Western blot analysis at the end of the acclimation period

\begin{tabular}{|c|c|c|c|c|c|c|}
\hline & \multicolumn{2}{|l|}{$18^{\circ} \mathrm{C}$} & \multicolumn{2}{|l|}{$22^{\circ} \mathrm{C}$} & \multicolumn{2}{|l|}{$28^{\circ} \mathrm{C}$} \\
\hline & Weight (g) & s.l. $(\mathrm{cm})$ & Weight (g) & s.l. (cm) & Weight (g) & s.l. $(\mathrm{cm})$ \\
\hline 1 & 21.3 & 10.2 & 30.7 & 12.0 & 23.9 & 11.0 \\
\hline 2 & 20.2 & 10.5 & 18.9 & 10.5 & 35.7 & 12.5 \\
\hline 3 & 22.2 & 11.0 & 32.8 & 12.0 & 29.1 & 11.0 \\
\hline 4 & 19.5 & 10.5 & 26.5 & 11.5 & 45.8 & 13.5 \\
\hline 5 & 14.5 & 10.0 & 30.0 & 12.0 & 25.6 & 11.0 \\
\hline 6 & 15.2 & 10.0 & 30.3 & 12.0 & 48.2 & 13.5 \\
\hline 7 & 9.8 & 9.0 & 33.5 & 12.5 & 33.1 & 12.5 \\
\hline 8 & 17.0 & 10.2 & 27.2 & 12.0 & 30.7 & 12.0 \\
\hline 9 & 31.1 & 12.0 & 26.6 & 11.0 & 42.3 & 13.3 \\
\hline 10 & 26.1 & 11.5 & 23.5 & 11.0 & 24.8 & 11.0 \\
\hline 11 & 23.8 & 11.5 & 19.0 & 9.5 & 40.7 & 13.0 \\
\hline 12 & 23.4 & 11.0 & 19.8 & 10.0 & 39.0 & 13.0 \\
\hline 13 & 27.7 & 12.0 & & & & \\
\hline 14 & 18.5 & 11.0 & & & & \\
\hline
\end{tabular}

times, respectively, compared with those acclimated at $18^{\circ} \mathrm{C}$.

\section{Foraging Test}

No temperature effect was found for latency to 'first bite' and in frequency of 'feeding' although the fish at $28^{\circ} \mathrm{C}$ showed a slight increase in the number of feeding events (19, on average) compared with the fish at 18 and $22^{\circ} \mathrm{C}$ (15-16, on average). 'Fin raising' behaviour was significantly more prevalent in fish acclimated to $28 \pm 1$ (SE) ${ }^{\circ} \mathrm{C}$ than in those at $18 \pm 1$ (SE) ${ }^{\circ} \mathrm{C}\left(\mathrm{H}_{2}=9.690, \mathrm{p}=0.0079\right)$ (Fig. 1a). Furthermore, the fish acclimated to the highest temperature spent more time in 'fast swimming' than individuals at the intermediate and lowest temperatures $\left(\mathrm{H}_{2}=\right.$ 11.366, $p=0.0034$ ) (Fig. lb). No tank effect within each experimental temperature was found ( $\mathrm{T}$ 18: $\mathrm{H}_{2}=6.946, \mathrm{p}=0.2247 ; \mathrm{T} 22: \mathrm{H}_{2}=8.829, \mathrm{p}=0.1161$; T 28: $\left.\mathrm{H}_{2}=10.191, \mathrm{p}=0.0700\right)$.

\section{Olfactory Test}

No temperature effect was found on the frequencies and durations of 'swimming close to the cue', 'contact with the cue' and 'interest in the cue' behaviour. However, a slight decrease in the time spent in the area around the cue was detected in the fish acclimated to the lower temperatures. In contrast, a temperature effect on the number of 'fin raising' events was found $\left(\mathrm{H}_{2}=12.861, \mathrm{p}=0.0016\right)$ in fish at $28 \pm 1(\mathrm{SE}){ }^{\circ} \mathrm{C}$. The levels displayed at this temperature were significantly higher than those observed at $18 \pm 1$ (SE) ${ }^{\circ} \mathrm{C}$ 

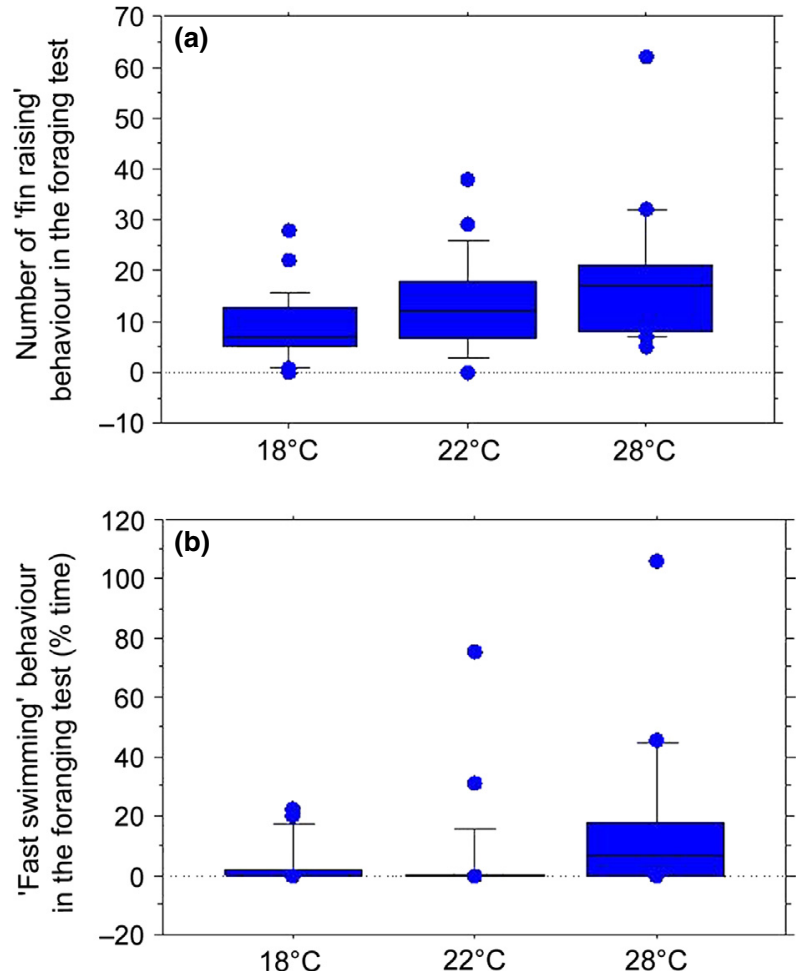

Fig. 1: Box plots summarising the distribution of the number of 'fin raising' behaviours $\left({ }^{*} 18^{\circ} \mathrm{C}\right.$ vs. $\left.28^{\circ} \mathrm{C}\right)(\mathrm{a})$ and the percentage time spent in 'fast swimming' behaviour $\left(* * 22^{\circ} \mathrm{C}\right.$ vs. $28^{\circ} \mathrm{C}$, $* 18^{\circ} \mathrm{C}$ vs. $\left.28^{\circ} \mathrm{C}\right)$ (b) in European sea bass relative to the three temperature treatments during the foraging test $(N=25)$. Each box plot contains a central line representing the median; the box itself delineates $25-75 \%$ of the data; the upper whisker represents the 90th percentile; the lower whisker represents the 10th percentile; and open circles represent outlying data points. $* p \leq 0.05, * * p \leq 0.01$

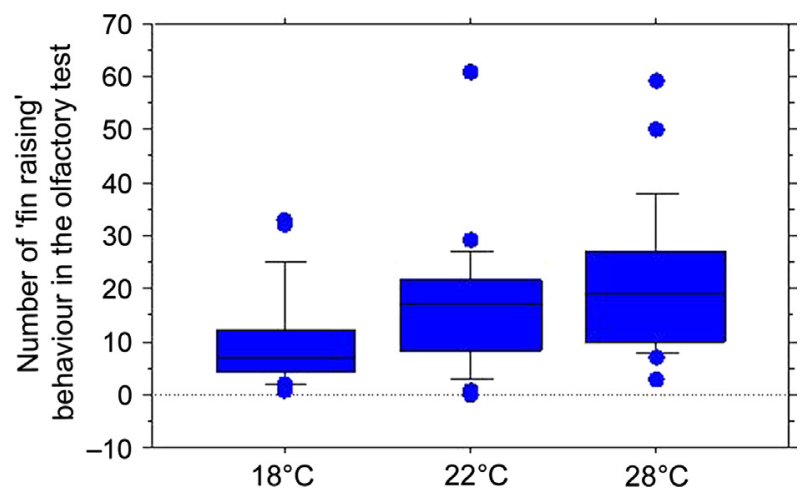

Fig. 2: Box plots summarising the distribution of the number of 'fin raising' behaviours $\left(* * 18^{\circ} \mathrm{C}\right.$ vs. $28^{\circ} \mathrm{C}, * 18^{\circ} \mathrm{C}$ vs. $\left.22^{\circ} \mathrm{C}\right)$ in European sea bass relative to the three temperature treatments during the olfactory test $(\mathrm{N}=25)$. Each box plot contains a central line representing the median; the box itself delineates $25-75 \%$ of the data; the upper whisker represents the 90th percentile; the lower whisker represents the 10th percentile; and open circles represent outlying data points. $* p \leq 0.05, * * p \leq 0.01$.
(Fig. 2). A tendency for this behaviour to occur more frequently at $22^{\circ} \mathrm{C}$ than at $18^{\circ} \mathrm{C}$ was also observed $(U=129.5$, tied p-value $=0.0309$, not significant following Bonferroni-Holm correction). No tank effect within each experimental temperature was found $(\mathrm{T}$ 18: $\mathrm{H}_{2}=5.215, \quad \mathrm{p}=0.3902 ; \mathrm{T} \quad 22: \mathrm{H}_{2}=7.463$, $\left.\mathrm{p}=0.1884 ; \mathrm{T} 28: \mathrm{H}_{2}=4.840, \mathrm{p}=0.4357\right)$.

\section{Aversive Test}

Approximately $96 \%$ of the fish acclimated to $18 \pm 1$ (SE) ${ }^{\circ} \mathrm{C}$ (24) and $100 \%$ of those at $28 \pm 1$ (SE) ${ }^{\circ} \mathrm{C}$ responded to the aversive stimulus applied at the middle of the tank, in contrast to $76 \%$ of the fish at $22 \pm 1(\mathrm{SE}){ }^{\circ} \mathrm{C}(19)$. The remaining fish could not be stimulated, as they remained motionless near the tank wall for the entire duration of the test session. As a result, AT did not throw the ball in this case. These fish were excluded from the statistical analysis. The fish at $28^{\circ} \mathrm{C}$ escaped more rapidly than the fish at $22^{\circ} \mathrm{C}$ $\left(\mathrm{H}_{2}=11.278, \quad \mathrm{p}=0.0036\right) \quad$ (Fig. 3). Temperature effects were not found either in the frequencies or in the durations of 'swimming close to the object', 'contact with the object', 'interest in the object' and 'freezing' (data not shown). In general, all fish spent a small percentage of time (on average, $1.6 \%$ ) in the area with the object and never touched it. However, 'freezing' behaviour was rarely observed (on average, $2.7 \%$ ). After exposure to the experimental stimulus, fish acclimated to $28 \pm 1(\mathrm{SE}){ }^{\circ} \mathrm{C}$ showed a tendency to remain inactive in the water column for more time than did fish acclimated to the other two temperatures $(U=192.0$, tied $\mathrm{p}$-value $=0.0190$ not significant after

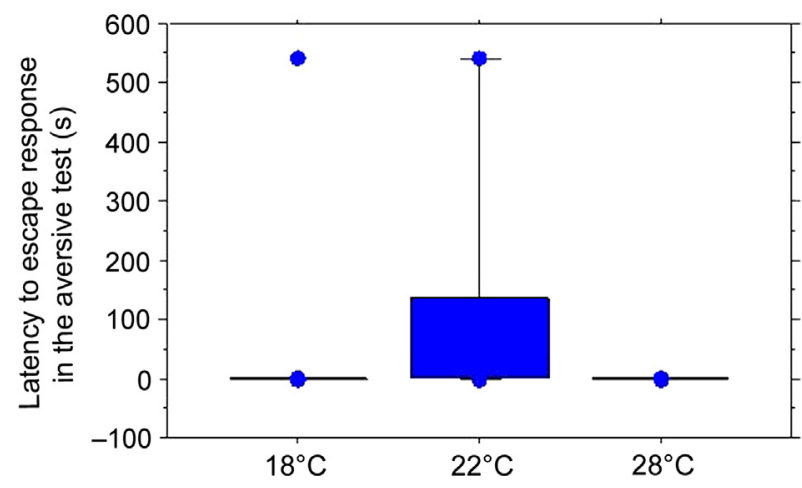

Fig. 3: Box plots summarising the distribution of the latency to escape response $\left(* * 22^{\circ} \mathrm{C}\right.$ vs. $\left.28^{\circ} \mathrm{C}\right)$ in European sea bass relative to the three temperature treatments during the aversive test $(\mathrm{N}=25)$. Each box plot contains a central line representing the median; the box itself delineates $25-75 \%$ of the data; the upper whisker represents the 90th percentile; the lower whisker represents the 10th percentile; and open circles represent outlying data points. $* p \leq 0.05, * * p \leq 0.01$. 
the correction of Bonferroni-Holm). No tank effect within each experimental temperature was found ( $\mathrm{T}$ 18: $\mathrm{H}_{2}=0.799 \quad \mathrm{p}=0.977 \mathrm{l} ; \quad \mathrm{T} \quad 22: \mathrm{H}_{2}=5.769$, $\left.\mathrm{p}=0.3293 ; \mathrm{T} 28: \mathrm{H}_{2}=2.828, \mathrm{p}=0.7265\right)$.

\section{Mirror Test}

In general, the fish acclimated to the intermediate temperature directed more behaviour to the mirror
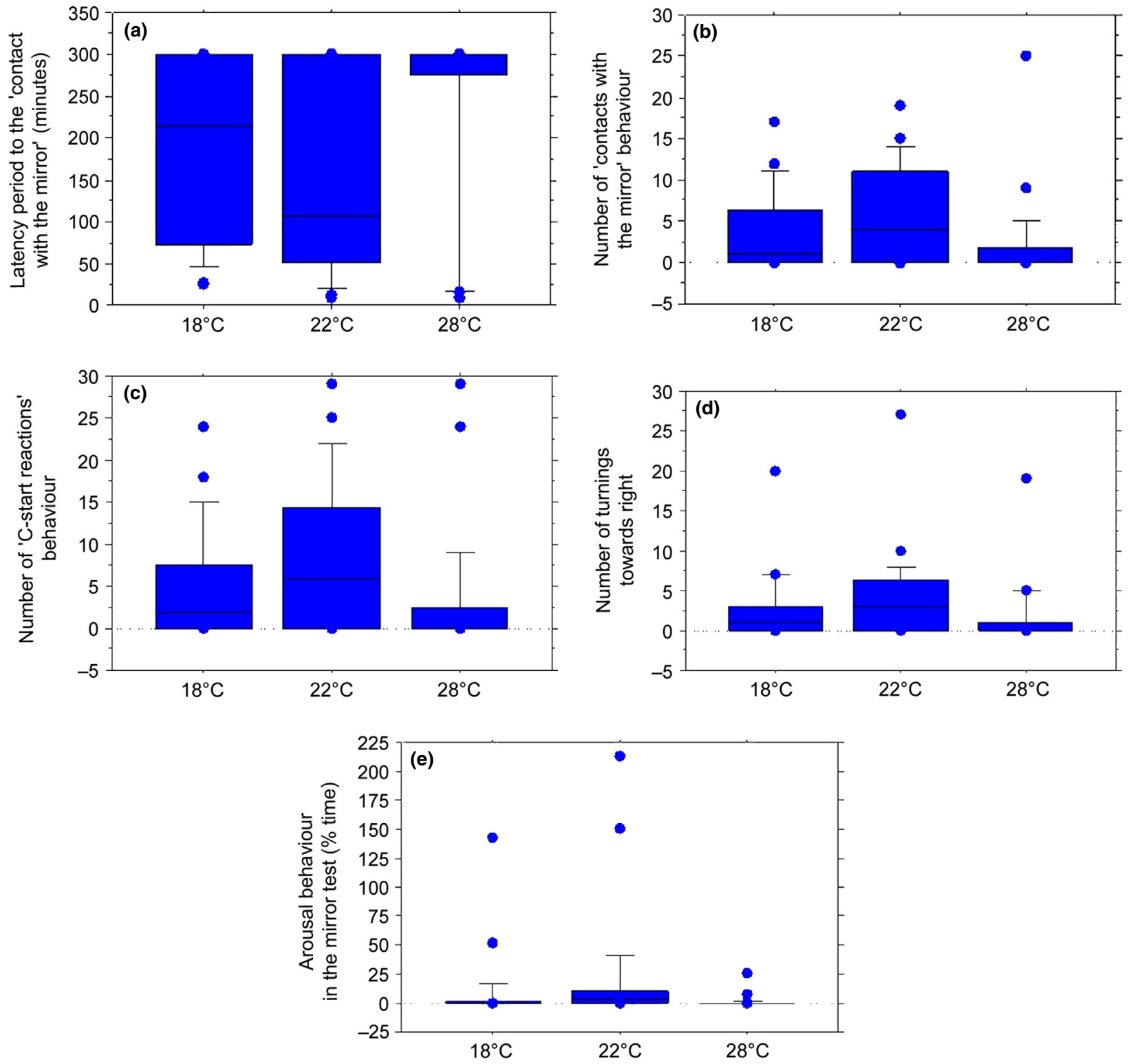

Fig. 4: Box plots summarising the distribution of latency to contact with the mirror $\left(* 22^{\circ} \mathrm{C}\right.$ vs. $28^{\circ} \mathrm{C}, 18^{\circ} \mathrm{C}$ vs. $\left.28^{\circ} \mathrm{C}\right)(a)$, the number of 'contact with the mirror' behaviours $\left(* * 22^{\circ} \mathrm{C}\right.$ vs. $\left.28^{\circ} \mathrm{C}\right)(\mathrm{b})$, the 'C-start reaction' behaviour $\left(* 22^{\circ} \mathrm{C}\right.$ vs. $\left.28^{\circ} \mathrm{C}\right)(\mathrm{C})$, the number of turns towards the right relative to the mirror $\left(* 22^{\circ} \mathrm{C}\right.$ vs. $28^{\circ} \mathrm{C}$ ) (d) and the percentage time spent in 'arousal' behaviour $\left(* * 22^{\circ} \mathrm{C}\right.$ vs. $\left.28^{\circ} \mathrm{C}\right)(\mathrm{e})$ in European sea bass relative to the three temperature treatments during the mirror test $(\mathrm{N}=25)$. Each box plot contains a central line representing the median; the box itself delineates $25-$ $75 \%$ of the data; the upper whisker represents the 90th percentile; the lower whisker represents the 10th percentile; and open circles represent outlying data points. $* p \leq 0.05, * * p \leq 0.01$. 
temperatures $\left(\mathrm{H}_{2}=6.544, \mathrm{p}=0.0379\right)$, with fish acclimated to $22 \pm 1$ (SE) ${ }^{\circ} \mathrm{C}$ showing significantly higher values than individuals at $28 \pm 1{ }^{\circ} \mathrm{C}$ (Fig. 4c). Furthermore, a temperature effect on the number of turns towards the right was found $\left(\mathrm{H}_{2}=8.262\right.$, $\mathrm{p}=0.0161)$, with fish at $18 \pm 1(\mathrm{SE}){ }^{\circ} \mathrm{C}$ and $22 \pm 1$ (SE) ${ }^{\circ} \mathrm{C}$ turning towards the right in $51 \%$ and $50 \%$, respectively, of the cases of 'C-start reaction' behaviour, whereas individuals at $28 \pm 1$ (SE) ${ }^{\circ} \mathrm{C}$ turned towards the right in approximately $40 \%$ of the cases (Fig. 4d). The mean number of 'C-start reaction' behaviours directed towards the right or towards the left did not differ within temperatures, even if fish acclimated to $22 \pm 1{ }^{\circ} \mathrm{C}$ showed higher values than individuals at $28 \pm 1{ }^{\circ} \mathrm{C}$.

The fish acclimated to $22 \pm 1$ (SE) ${ }^{\circ} \mathrm{C}$ spent significantly more time displaying 'arousal' behaviour in the proximity of the mirror $\left(\mathrm{H}_{2}=10.135, \mathrm{p}=0.0063\right)$, whereas the fish at $28 \pm 1{ }^{\circ} \mathrm{C}$ showed the smallest amount of time displaying this behaviour (Fig. 4e).

No tank effect within each experimental temperature was found ( $\mathrm{T}$ 18: $\mathrm{H}_{2}=3.650, \mathrm{p}=0.6009 ; \mathrm{T}$ 22: $\mathrm{H}_{2}=1.507, \mathrm{p}=0.9123 ; \mathrm{T}$ 28: $\mathrm{H}_{2}=1.830$, $\mathrm{p}=0.8721)$.

\section{Analysis of ChAT Expression}

A total of 38 fish ( 14 specimens acclimated at $18^{\circ} \mathrm{C}, 12$ at $22^{\circ} \mathrm{C}$ and 12 at $28^{\circ} \mathrm{C}$ ) captured haphazardly with a hand net from those previously subjected to behavioural tests were euthanised, measured and used for neurochemical analyses.

ChAT levels were analysed in protein homogenates from the brain and spinal cord of fish previously subjected to behavioural tests. This analysis used a polyclonal antibody against human ChAT. The same antibody has been used successfully in a WB analysis performed on the whole-brain homogenates of European sea bass juveniles (Malavasi et al. 2013). Its cellular reactivity was verified by immunofluorescence on brain sections of the midbrain tectum, where densely packed unipolar neurons with apical dendrites (arrowheads) were stained in the periventricular stratum (arrows) of the laminated tectum (Fig. 5b,c). These cells display ChAT immunoreactivity in all teleosts studied to date, including trout (Pérez et al. 2000), zebrafish (Clemente et al. 2004) and goldfish (Zottoli et al. 1987; Giraldez-Perez et al. 2009). Thus, the mammalian polyclonal antibody is able to cross-react with sea bass ChAT.

A WB analysis of regional ChAT expression from fish acclimated at $18 \pm 1(\mathrm{SE}){ }^{\circ} \mathrm{C}$ revealed that the polyclonal antibody labelled an intense ChAT immu- noreactive band at approximately $70-75 \mathrm{kDa}$ (Fig. 5d). A quantitative evaluation of the immunolabelled bands showed that the ChAT band was more intense in the mesencephalon (midbrain/optic tectum), the diencephalon and the brainstem followed by the cerebellum, the spinal cord and the telencephalon homogenates. In particular, the highest ChAT level was detected in the optic tectum and the lowest in the telencephalon, with a an eightfold difference between the highest and lowest levels (Fig. 5d). The comparison of brain ChAT expression in the wholebrain homogenates from fish acclimated to $18 \pm 1$, $22 \pm 1$ and $28 \pm 1(\mathrm{SE}){ }^{\circ} \mathrm{C}$ revealed higher ChAT levels at $22 \pm 1{ }^{\circ} \mathrm{C}$ and $28 \pm 1(\mathrm{SE}){ }^{\circ} \mathrm{C}$ than in $18 \pm 1$ (SE) ${ }^{\circ} \mathrm{C}$ (Fig. 5e). Regional ChAT expression at the three temperatures revealed a significant increase in the telencephalon (a), diencephalon (b), cerebellum (d) and the spinal cord (f) at $22 \pm 1$ (SE) ${ }^{\circ} \mathrm{C}$ and $28 \pm 1{ }^{\circ} \mathrm{C}$ relative to $18 \pm 1{ }^{\circ} \mathrm{C}$ (Fig. $5 \mathrm{f}-\mathrm{g}$ ). Conversely, a decrease in ChAT expression levels was detected in the optic tectum at $22 \pm 1$ (SE) ${ }^{\circ} \mathrm{C}$ and $28 \pm 1^{\circ} \mathrm{C}$ relative to $18 \pm 1^{\circ} \mathrm{C}$.

\section{Discussion}

Present findings indicate that thermal conditions influence both behaviour and central ChAT neurochemistry in the European sea bass. After $3 \mathrm{wk}$ at 18,22 and $28^{\circ} \mathrm{C}$, feeding behaviour was not affected by temperature, whereas fin raising and fast swimming were clearly affected by thermal conditions. Following the temperature acclimation period at $28 \pm 1{ }^{\circ} \mathrm{C}$, fish showed higher values of these two behaviours compared with fish maintained at lower temperatures in the presence of living prey and olfactory cues. Furthermore, fin raising events and the time spent in rapid swimming increased linearly across the three temperatures $\left(28^{\circ} \mathrm{C}>22^{\circ} \mathrm{C}>18^{\circ} \mathrm{C}\right)$. Pickett \& Pawson (1994) noted these two behaviours as foraging-linked behavioural patterns, representing a response indicating an awareness of the presence of food in D. labrax. Indeed, high temperatures have been found to be correlated with increases in food demand in sea bass (Claireaux $\delta$ Lagardere 1999; Peres \& Oliva-Teles 1999; Person-Le Ruyet et al. 2004). Higher body growth in fish at $28^{\circ} \mathrm{C}$ could also have affected their behaviour in presence of food, even if no temperature effect on food consumption and/or on latency to feed in the foraging test was detected in this study. Furthermore, it should be noted that this increase of size has been measured only in a sub-sample of animals. The occurrence of an increased temperature 

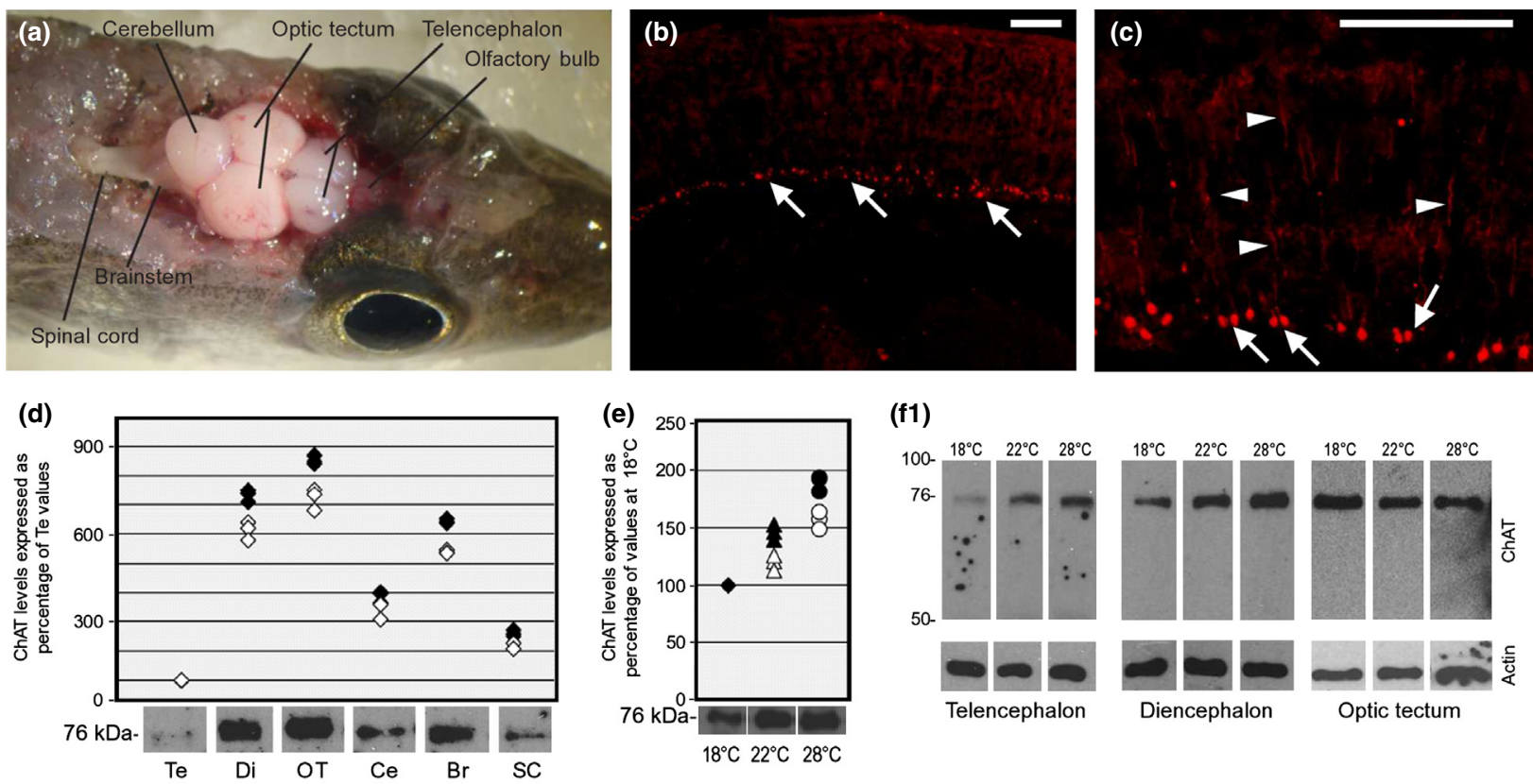

(f1)

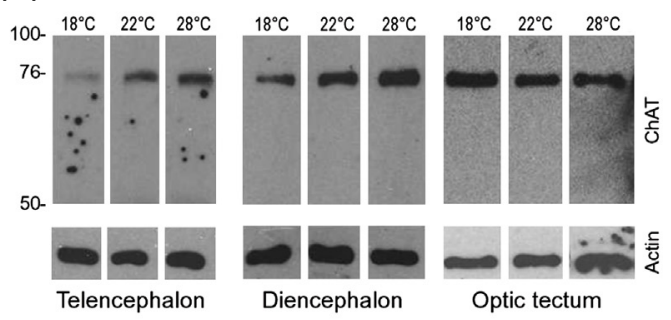

(f2)

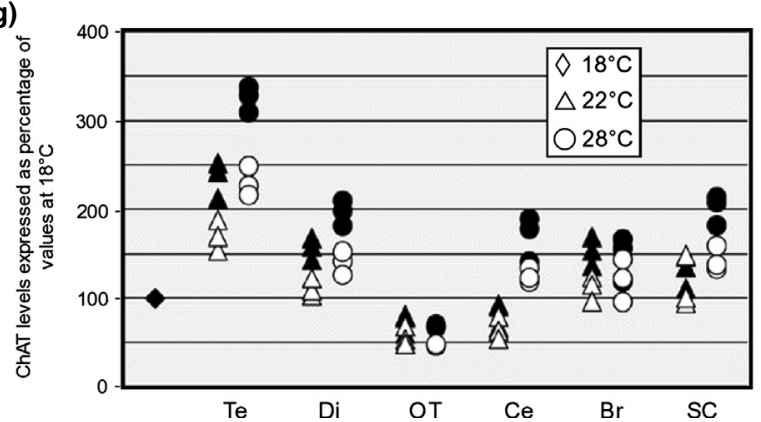

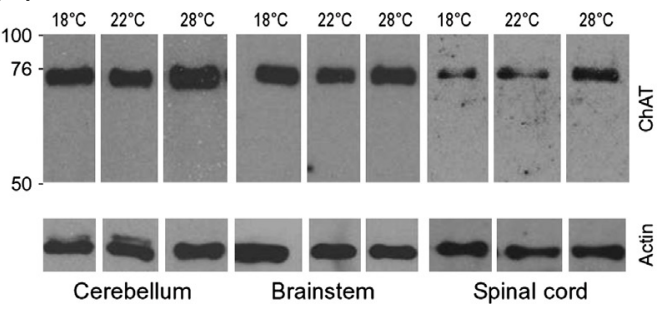

Fig. 5: ChAT expression in the brain and spinal cord of fish acclimated to different temperatures. Brain and spinal cord regions analysed with the Western blot method are shown in a freshly dissected fish (a). (b, c) ChAT immunofluorescence performed on 20- $\mu$ m-thick frozen sections of the midbrain optic tectum. Arrows point to the unipolar neurons of the periventricular stratum and arrowheads to their apical processes. Bar $=100 \mu \mathrm{m}$. (d) ChAT expression levels analysed with the Western blot method in telencephalon (Te), diencephalon (Di), optic tectum (OT), cerebellum (Ce), brainstem $(\mathrm{Br})$ and spinal cord (SC) of specimens acclimated to $18^{\circ} \mathrm{C}$ (lower panel). Quantification of ChAT levels by normalisation on actin levels (upper panel). For each encephalic region, two pools of tissues from three fish were analysed in triplicate. Single observations are reported. White and black rhombuses discriminate data on the two different pools of tissues. (e) ChAT expression levels in the whole-brain homogenates of specimens acclimated to $18 \pm 1(\mathrm{SE}){ }^{\circ} \mathrm{C}, 22 \pm 1{ }^{\circ} \mathrm{C}$ and $28 \pm 1{ }^{\circ} \mathrm{C}$ (lower panel). Quantification of ChAT levels by normalisation on GAPDH levels (upper panel). For each temperature, two pools of whole brains from three fishes were analysed in triplicate. Single data are reported as rhombuses $\left(18^{\circ} \mathrm{C}\right)$, triangles $\left(22^{\circ} \mathrm{C}\right)$ and circles $\left(28^{\circ} \mathrm{C}\right)$. White and black colours discriminate data on the two different pools of tissues. (f) Comparison of ChAT levels in the main encephalic regions and spinal cord of fish acclimated to given temperatures (18 \pm 1 (SE) ${ }^{\circ} \mathrm{C}, 22 \pm 1{ }^{\circ} \mathrm{C}, 28 \pm 1^{\circ} \mathrm{C}$ ). (g) Quantification of ChAT protein expression levels normalised on actin levels. For each encephalic region, two pools of tissues from three fishes were analysed in triplicate. Single data are reported as rhombuses $\left(18^{\circ} \mathrm{C}\right)$, triangles $\left(22^{\circ} \mathrm{C}\right)$ and circles $\left(28^{\circ} \mathrm{C}\right)$. White and black colours discriminate data on the two different pools of tissues.

dependence of overall activity may also serve to explain our observations.

In this context, the more rapid escape response performed by fish at $28^{\circ} \mathrm{C}$ can be explained by a generalised high responsiveness to the environment. However, all fish, independent of the temperature at which they were housed, showed a fright response to the ball thrown into the tanks, confirming the flight response as an innate behavioural component of their defence behaviour.

In this study, the response to a mirror image was used to investigate temperature-dependent social responses in the sea bass. Responses of fish to mirrors have been observed in several different contexts, including predator avoidance (Milinski 1987; Bisazza et al. 1999) and agonistic encounters (Meliska et al. 
1980; Bronstein 1985). Furthermore, fish recognise unusual characteristics of the mirror image in comparison with a real fish image, showing a differential brain response that may reflect a cognitive distinction involving fear experience (Desjardins \& Fernald 2010). Moreover, C-start movements have been described during hatching and feeding (Canfield $\delta$ Rose 1993). The relatively high latency periods observed in this study suggest that the fish showed a cautious approach to the mirror at both the lowest and the highest temperature tested. The fish at the intermediate temperature $\left(22 \pm 1(\mathrm{SE}){ }^{\circ} \mathrm{C}\right)$ displayed major interest in the mirror test, interacting with the stimulus more rapidly and for a longer time than at the extreme temperatures of the tested range, thus exhibiting C-start reactions and the highest arousal levels. Accordingly, zigzag swimming, buccal pumping and dorsal fin movements around and towards the mirror were primarily found in the fish maintained at $22^{\circ} \mathrm{C}$. This observation indicated a general state of excitement resulting from the stimulus and most likely associated with agonistic behaviour (Pickett \& Pawson 1994). Responses such as gill erection and bites directed towards the mirror have also been interpreted in terms of aggressive motivation (Meliska et al. 1980). Unfortunately, the distension of the opercula, sometimes associated with agonistic posturing in the sea bass (Pickett $\&$ Pawson 1994), could not be measured in the current study because the movements of the fish did not allow this pattern to be followed for the entire duration of the test. Several studies have observed optimal growth rates and feed conversion efficiency in the sea bass at $22^{\circ} \mathrm{C}$ relative to cooler $\left(16^{\circ} \mathrm{C}\right)$ and warmer $\left(29^{\circ} \mathrm{C}\right)$ waters (Gardeur et al. 2001; Pichavant et al. 2001; Person-Le Ruyet et al. 2004). According to these studies, the mirror responsiveness shown by fish at $22^{\circ} \mathrm{C}$ may represent an indirect measurement of good health status in terms of a strong propensity for social interaction, including aggressive/fear displays. The results of the WB analysis demonstrated that temperature acclimation involves region-specific modulation of ChAT expression. In particular, a general increase in ChAT expression was found in most brain and spinal regions of the fish acclimated to $22^{\circ} \mathrm{C}$ and $28 \pm 1^{\circ} \mathrm{C}$ relative to the fish acclimated at $18 \pm 1^{\circ} \mathrm{C}$. The opposite pattern was observed in the midbrain optic tectum. This finding suggests that ChAT levels are not directly related to the metabolic rate but are specifically modulated in different brain centres.

In the present study, the variation of ChAT expression was analysed as a valuable marker for neuronal activity in the CNS. Therefore, ChAT expression must not be understood as an indirect measure of the amount of ACh in the brain vesicles because the concentration of this neurotransmitter depends on its synthesis by ChAT and its degradation by AChE. However, given the behavioural results, the almost generalised increase of ChAT protein expression in the brain and spinal cord homogenates might be related to the large amount of ACh required by cranial and spinal motoneurons to regulate the improved motor performances observed in fish acclimated to high temperatures in comparison with fish acclimated at $18^{\circ} \mathrm{C}$.

ChAT levels also increase in the forebrain (telencephalon and diencephalon) in response to thermal conditions. Because the first response of fish to thermal changes is typically behavioural and involves migration to a more thermostable microenvironment, the increased ChAT expression in the forebrain may be related to the neuroendocrine activation of behavioural thermoregulation. In this context, experiments in goldfish have demonstrated that behavioural thermoregulation is mediated by $\mathrm{ACh}$ and that the amount of ACh in the preoptic region and the basal telencephalon can affect the ambient temperature selected by the fish (Crawshaw \& Wollmuth 1992). The increased ChAT expression found in the cerebellum in the current study is in agreement with the increase in ChAT activity found in goldfish acclimated from 5 to $22^{\circ} \mathrm{C}$ and $35^{\circ} \mathrm{C}$ (Poli et al. 1997). In contrast to all other brain regions, the optic tectum showed a decrease in ChAT expression in the sea bass acclimated to high temperatures. This finding suggests that ChAT levels are not merely related to the metabolic rate but are differentially modulated in the brain centres. The midbrain tectum is involved in visual processing, and it is also one of the main sensorimotor integration centres of the teleostean CNS (Meek \& Nieuwenhuys 1998). The decrease in ChAT levels in this region could be responsible for changes in the coordination of movements.

Studies from our group have recently demonstrated that ChAT expression decreases in the whole-brain homogenates of wild juvenile sea bass (s.l. $3-4 \mathrm{~cm}$ ) acclimated at $26^{\circ} \mathrm{C}$ relative to those acclimated at $18^{\circ} \mathrm{C}$ (Malavasi et al. 2013). The discrepancy in ChAT expression between wild sea bass juveniles (s.l. 3-4 cm) and juveniles (s.l. $10 \mathrm{~cm}$ ) from a commercial hatchery could be related to the difference in ages and/or to the genetic variability of the populations analysed. In fact, cholinergic systems may fulfil different roles in response to environmental changes occurring at different life stages. 
However, the differences in ChAT regulation following thermal changes could arise from putative genetic differences between wild juvenile sea bass captured in the Venetian Lagoon and juveniles provided by a commercial hatchery. Nevertheless, both experiments provide evidence that the activity of cholinergic neurons is modulated in response to external temperature. Different sea bass populations of the same age should be examined to clarify the role of genetic and developmental factors in the response of the cholinergic system to thermal changes.

Fish maintained at $28^{\circ} \mathrm{C}$ showed more rapid growth than fish maintained at $22^{\circ} \mathrm{C}$ and $18^{\circ} \mathrm{C}$, as expected, although these data were obtained from a sub-sample from each experimental group. Body size is known to affect aggressive and competitive behaviour if food resources are severely limited (Knights 1987; Dugatkin \& Reeve 1998). In the present study, the scarcity of food was not tested as experimental condition and the size-dependent competitive behaviour could not to be considered because fish pairs were similar in body size within each thermal treatment. Aggressive behaviour was indirectly considered in the mirror test because the fish's own image induced a response. Even in this case, no evidence was found that body size affected the observed behaviour. Finally, no data in the literature suggest or support an effect of body size on ChAT expression levels. Nevertheless, such effects cannot be excluded on the basis of the present experiments. Future studies of groups of differentsized fish will be aimed at obtaining a specific clarification of the effect of body size on the behaviour of thermally acclimated fish.

Overall, the present findings suggest that water temperature exerts an impact on certain aspects of both behaviour and CNS neurochemistry in juvenile European sea bass. In the present experiments, we exposed the fish to $3 \mathrm{wk}$ of thermal acclimation. This experimental condition should be viewed as 'longterm' rather than 'short-term' acclimation, which, instead, involves acute responses of membranes/molecules within minutes or hours.

The present results point to putative effects of physical parameters such as water temperature on CNS activity and fish behaviour. Given the commercial value of European sea bass and the extensive systems of farming in which it is involved, these effects need to be monitored. Our data may be helpful in the context of aquaculture, for example net pen systems, in which animals cannot migrate to cooler water.

\section{Acknowledgements}

We express our thanks to Panittica Pugliese s.r.l. for generously supplying the fish used in this study. We also thank Dr Maria Carmela Bonaccorsi di Patti for her scientific support, Dr Flavia Chiarotti for her statistical support, Mrs Stella Falsini for collecting references, Mrs Mariangela Coriandri for her valuable help with animal care and Dr Augusto Vitale for a critical reading of the manuscript.

\section{Funding}

This work was performed within the Consortium for Coordination of Research Activities Concerning the Venetian Lagoon System (CORILA) research project 'Analisi neurochimica e comportamentale degli effetti del cambiamento climatico e conseguente aumento della temperatura sull'attività del sistema nervoso centrale nelle specie ittiche di interesse alieutico spigola (Dicentrarchus labrax) e orata (Sparus aurata)', financially supported by Regione Veneto in the context of 'fondi della Legge Speciale per Venezia, nell'ambito del programma finalizzato all'acquisizione di nuove conoscenze per la salvaguardia della laguna di Venezia, del bacino scolante e del mare antistante'. This work was also supported in part by the Sapienza University of Rome [Progetti di Ricerca 2010].

\section{Conflict of Interest}

All of the authors declare no conflict of interest.

\section{Literature Cited}

Aickin, M. \& Gensler, H. 1996: Adjusting for multiple testing when reporting research results: the Bonferroni vs Holm methods. Am. J. Public Health 86, 726-728.

Atema, J. 1980: Chemical sense, chemical signals, and feeding behavior in fishes. In: Fish Behaviour and its Use in the Capture and Culture of Fishes (Bardach, J. E., Magnuson, J. J., May, R. C. \& Reinhart, J. M., eds). International Center for Living Aquatic Resources Management, Manila, pp. 57-101.

Atkinson, D. 1996: Ectotherm life-history responses to developmental temperature. In: Animals and temperature: phenotypic and evolutionary adaptation. (Johnston, I. A., Bennett, A. F., eds). Cambridge Univ. Press, Cambridge, pp. 183-204.

Barnabé, G. 1991: Grossissement des poissons en élevage intensif. In: Bases biologiques et écologiques de l'aquaculture. (Barnabé, G., ed). Lavoisier Tec \& Doc, Paris, pp. $422-451$. 
Bisazza, A., De Santi, A. \& Vallortigara, G. 1999: Laterality and cooperation: mosquitofish move closer to a predator when the companion is on their left side. Anim. Behav. 57, 1145-1149.

Blaber, S. J. M., Brewer, D. T. \& Salini, J. P. 1989: Species composition and biomass of fishes in different habitats of a tropical northern Australian estuary: their occurrence in the adjoining sea and estuarine dependence. Estuar. Coast. Shelf Sci. 29, 509-531.

Bronstein, P. M. 1985: Predictors of dominance in male Betta splendens. J. Comp. Psychol. 99, 47-55.

Brown, C., Davidson, T. \& Laland, K. 2003: Environmental enrichment and prior experience of live prey improve foraging behavior in hatchery-reared Atlantic salmon. J. Fish Biol. 63(Suppl. A), 187-196.

Cairns, M. A., Ebersole, J. L., Baker, J. L., Wigington, P. J., Lavigne, H. R. \& Davis, S. M. 2005: Influence of summer stream temperatures on black spot infestation of juvenile Coho salmon in the Oregon Coast Range. Trans. Am. Fish. Soc. 134, 1471-1479.

Canfield, J. G. \& Rose, G. J. 1993: Activation of Mauthner neurons during prey capture. J. Comp. Physiol. A. 172, $611-618$.

Chang, P. H. \& Plumb, A. 1996: Effects of salinity on Streptococcus infection of Nile Tilapia, Oreochromis niloticus. J. Appl. Aquac. 6, 39-45.

Claireaux, G. \& Lagardere, J. P. 1999: Influence of temperature, oxygen and salinity on the metabolism of the European sea bass. J. Sea Res. 42, 157-168.

Claireaux, G., Couturier, C. \& Groison, A. L. 2006: Effect of temperature on maximum swimming speed and cost of transport in juvenile European sea bass (Dicentrarchus labrax). J. Exp. Biol. 200, 3420-3428.

Clemente, D., Porteros, A., Weruaga, E., Alonso, J. R., Arenzana, F. J., Aijón, J. \& Arévalo, R. 2004: Cholinergic elements in the zebrafish central nervous system: histochemical and immunohistochemical analysis. J. Comp. Neurol. 474, 75-107.

Cossins, A. R. \& Bowler, K., 1987: Temperature Biology of Animals. Chapman \& Hall, London.

Crawshaw, L. I. \& Wollmuth, L. P. 1992: Effective loci and roles of acetylcholine in temperature regulation of goldfish. Am. J. Physiol. 263, 596-601.

Daufresne, M. 2009: Impacts of climatic and non-climatic pressures on fish communities in large French rivers. Hydroecol. Appl. 16, 109-134.

Desjardins, J. K. \& Fernald, R. D. 2010: What do fish make of mirror immages? Biol. Lett. 6, 744-747.

Dias, J., Gomes, E. F. \& Kaushik, S. J. 1997: Improvement of feed intake through supplementation with an attractant mix in European seabass fed plant-protein rich diets. Aquat. Living Resour. 10, 385-389.

Dugatkin, L. A. \&. \& Reeve, H. K. 1998. Game Theory and Animal Behavior. Oxford Univ. press, Oxford, $336 \mathrm{pp}$.
Eckenstein, F., Barde, Y. A. \& Thoenen, H. 1981: Production of specific antibodies to choline acetyltransferase purified from pig brain. Neuroscience 6, 993-1000.

Eisenreich, S. J., 2005: Climate Changes and the European Water Dimension. A Report to the European Water Directors. European Commission, EUR 21553, Bruxelles.

European Commission (EC) 2007: Recommendation 2007/526/EC of 18 June 2007 on guidelines for the accommodation and care of animals used for experimental and other scientific purposes (notified under document number C(2007) 2525) (Text with EEA relevance). Off. J. Eur. Union L197: 1-89.

European Union (EU) 2010: Directive 2010/63/EU of the European Parliament and of the Council of 22 September 2010 on the protection of animals used for scientific purposes. Off. J. Eur. Union L276:33-79.

Gardeur, J. N., Lemarié, G., Coves, D. \& Boujard, T. 2001: Typology of individual growth in sea bass (Dicentrarchus labrax). Aquat. Living Resour. 14, 223-231.

Giffard-Mena, I., Boulo, V., Abed, C., Cramb, G. \& Charmantier, G. 2011: Expression and localization of Aquaporin $1 \mathrm{a}$ in the sea-bass (Dicentrarchus labrax) during ontogeny. Front. Physiol 34, 1-13.

Giraldez-Perez, R. M., Gaytan, S. P., Torres, B. \& Pasaro, R. 2009: Co-localization of nitric oxide synthase and choline acetyltransferase in the brain of the goldfish (Carassius auratus). J. Chem. Neuroanat. 37, 1-17.

Hara, J. T. 1993: Role of olfaction in fish behavior. In: Behaviour of teleost fishes, 2nd edn. (Pitcher, T. J., ed). Chapman \& Hall, London, pp. 171-199.

Hebb, C., Stephens, T. C. \& Smith, M. W. 1972: Effect of environmental temperature on the kinetic properties of goldfish brain choline acetyltransferase. Biochem. J. 129, 1013-1021.

Hiddink, J. G. \& ter Hofstede, R. 2008: Climate induced increases in species richness of marine fishes. Glob. Change Biol. 14, 453-460.

Idler, D. R., McBride, J. R., Jonas, R. E. E. \& Tomlinson, N. 1961: Olfactory perception in migrating salmon. II. Studies on a laboratory bioassay for home stream water and mammalian repellent. Can. J. Biochem. Physiol. 39, 1575-1584.

Intergovernmental Panel on Climate Change (IPCC), eds 2007: Climate Change 2007: Synthesis Report. IPCC Secretariat, Geneva, Switzerland. Available at htpp:// www.ipcc.ch/pdf/assessment report/ar4/syr/ ar4_syr.pdf.

Jobling, M. 1996: Temperature and growth: modulation of growth rate via temperature. In: Global Warning: Implication for Freshwater and Marine Fish. Society for Experimental Biology (Wood, C. M. \& McDonald, D. G., eds). Cambridge Univ. Press, Cambridge, pp. 225-253.

Kankaala, P., Ojala, A., Tulonen, T. \& Arvola, L. 2002: Changes in nutrient retention capacity of boreal aquatic 
ecosystems under climate warming: a simulation study. Hydrobiologia 469, 67-76.

Knights, B. 1987: Agonistic behaviour and growth in the European eel, Anguilla anguilla L., in relation to warmwater aquaculture. J. Fish Biol. 31, 265-276.

Koumoundouros, G., Sfakianakis, D. G., Divanach, P. \& Kentouri, M. 2002: Effect of temperature on swimming performance of sea bass juveniles. J. Fish Biol. 60, 923-932.

Mackie, A. M. \& Mitchell, A. T. 1982. Chemical ecology and chemoreception in the marine environment. In: Indices biochimiques et milieux marins. Actes et Colloques, Publication CNEXO, 14, 11-24.

Malavasi, S., Cipolato, G., Cioni, C., Torricelli, P., Alleva, E., Manciocco, A. \& Toni, M. 2013: Effects of temperature on the antipredator behaviour and on the cholinergic expression in the European sea bass (Dicentrarchus labrax L.) juveniles. Ethology 119, 592-604.

Manciocco, A., Calamandrei, G. \& Alleva, E. 2014: Global warming and environmental contaminants in aquatic organisms: The need of the etho-toxicology approach. Chemosphere 100, 1-7.

Meek, J. \& Nieuwenhuys, R. 1998: Holosteans and teleosts. In: The Central Nervous System of Vertebrates, Vol. 2 (Nieuwenhuys, R., ten Donkelaar, H. J. \& Nicholson, C., eds). Springer-Verlag, Berlin, pp. 759-937.

Meliska, C. J., Meliska, J. A. \& Peeke, H. V. S. 1980: The relationship of mirror-elicited display to combat behaviors in Betta splendens. Behav. Neural Biol. 30, $207-217$.

Miklosi, A., Andrew, R. J. \& Savage, H. 1998: Behavioural lateralization of the tetrapod type in the zebrafish (Brachydanio rerio). Physiol. Behav. 63, 127-135.

Milinski, M. 1987: TIT FOR TAT in sticklebacks and the evolution of cooperation. Nature 325, 433-435.

Navarro-Martin, L., Vinas, J., Ribas, L., Diaz, N., Gutierrez, A., Di Croce, L. \& Piferrer, F. 2011: DNA methylation of the gonadal aromatase (cyp19a) promoter is involved in temperature-dependent sex ratio shifts in the European sea bass. PLoS Genet. 7, 1-15.

Peres, H. \& Oliva-Teles, A. 1999: Influence of temperature on protein utilization in juvenile European seabass (Dicentrarchus labrax). Aquaculture 102, 337-348.

Pérez, S. E., Yáñez, J., Marín, O., Anadón, R., González, A. \& Rodríguez-Moldes, I. 2000: Distribution of choline acetyltransferase (ChAT) immunoreactivity in the brain of the adult trout and tract-tracing observations on the connections of the nuclei of the isthmus. J. Comp. Neurol. 18, 450-474.

Perneger, T. V. 1998: What wrong with Bonferroni adjustments. BMJ 316, 1236-1238.

Person-Le Ruyet, J., Mahe, K., Le Bayon, N. \& Le Delliou, H. 2004: Effects of temperature on growth and metabolism in a Mediterranean population of European sea bass, Dicentrarchus labrax. Aquaculture 237, 269-280.
Pichavant, K., Person-Le Ruyet, J., Le Bayon, N., Sévère, A., le Roux, A. \& Boeuf, G. 2001: Comparative effects of long-term hypoxia on growth, feeding and oxygen consumption in juvenile turbot and European sea bass. J. Fish Biol. 59, 875-883.

Pickett, G. D. \& Pawson, M. G. 1994: Sea Bass: Biology, Exploitation and Conservation. Chapman \& Hall, London.

Poli, A., Notari, S., Virgili, M., Fabbri, E. \& Lucchi, R. 1997: Neurochemical changes in cerebellum of goldfish exposed to various temperatures. Neurochem. Res. 22, $141-149$.

Pörtner, H. O. 2002: Climate variations and the physiological basis of temperature dependent biogeography: systemic to molecular hierarchy of thermal tolerance in animals. Comp. Biochem. Physiol. Part A 132, 739761.

Russell, W. M. S. \& Burch, R. L. 1959: The Principles of Humane Experimental Technique. Universities Federation for Animal Welfare, Wheathampstead, England.

Russell, N. R., Fish, J. D. \& Wootton, R. J. 1996: Feeding and growth of juvenile sea bass: the effect of ration and temperature on growth rate and efficiency. J. Fish Biol. 49, 206-220.

Saillant, E., Fostier, A., Pierrick, H., Menu, B., Thimonier, J. \& Chatain, B. 2002: Temperature effects and genotype-temperature interactions on sex determination in the European sea bass (Dicentrarchus labrax L.). J. Exp. Zool. 292, 494-505.

Salvaterra, P. M. \& McCaman, R. E. 1985: Choline acetyltransferase and acetylcholine levels in Drosophila melanogaster: a study using two temperature-sensitive mutants. J. Neurosci. 5, 903-910.

Sehdev, H. S., McBride, J. R. \& Fagerland, U. H. M. 1963: 2-phenoxyethanol as a general anaesthetic for sockeye salmon. J. Fish. Res. Board Can. 20, 1435-1440.

Sfakianakis, D. G., Georgakopoulou, E., Papadakis, I. E., Divanach, P., Kentouri, M. \& Koumoundouros, G. 2006: Environmental determinants of haemal lordosis in European sea bass, Dicentrarchus labrax (Linnaeus, 1758). Aquaculture 254, 54-64.

Tajima, Y. \& Salvaterra, P. M. 1992: Positive and negative feedback regulation of choline acetyltransferase mRNA levels in Drosophila: a study using temperature-sensitive mutants and embryo cell cultures. Brain Res. Mol. Brain Res. 13, 213-221.

Takagawa, K. \& Salvaterra, P. 1996: Analysis of choline acetyltransferase protein in temperature sensitive mutant flies using newly generated monoclonal antibody. Neurosci. Res. 24, 237-243.

Tsubokawa, T., Saito, K., Kawano, H., Kawamura, K., Shinozuka, K. \& Watanabe, S. 2009: Pharmacological effects on mirror approaching behaviour and neurochemical aspects of the telencephalon in the fish, medaka (Oryzias latipes). Soc. Neurosci. 9, 1-11. 
Vinagre, C., Ferreira, T., Matos, L., Costa, M. J. \& Cabral, H. N. 2009: Latitudinal gradients in growth and spawning of sea bass, Dicentrarchus labrax, and their relationship with temperature and photoperiod. Estuar. Coast. Shelf Sci. 81, 375-380.
Zottoli, S. J., Rhodes, K. J. \& Mufson, E. J. 1987: Comparison of acetylcholinesterase and choline acetyltransferase staining patterns in the optic tectum of the goldfish Carassius auratus. A histochemical and immunocytochemical analysis. Brain Behav. Evol. 30, 143-159. 